\title{
Determining the Relationship between Preschool Teachers' Attitudes towards Science Teaching and Self-efficacy Beliefs in Terms of Various Variables
}

\author{
Neslihan Ültay, Eser Ültay*, Hatice YıImazer \\ Department of Elementary Education, Faculty of Education, Giresun University, Giresun, Turkey \\ *Corresponding Author: eserultay@gmail.com
}

\section{ABSTRACT}

The aim of this study was to determine the relationship between preschool teachers' attitudes toward science teaching and self-efficacy beliefs and to examine them in terms of various variables. The research was conducted in the years 2018-2019 using a survey. The study included 113 female and eight male preschool teachers who worked in state or private schools in Turkey. All participated voluntarily. In this study, the "Scale of Attitudes toward Science Teaching" (AST) and "Science Teaching Self-Efficacy Beliefs Scale" (SEB) were used. Both scales used five-point Likert type items. After the scales were applied, semi-structured interviews were conducted with 36 randomly selected teachers and five open-ended questions developed by the researchers were asked. In the light of the findings obtained from the study, it was observed that pre-school teachers' attitudes toward science teaching and science self-efficacy beliefs did not differ according to gender and professional experience. In addition, there was a positive relationship between teachers' scores obtained from the AST and SEB, that is, science attitudes and science self-efficacy beliefs were related positively. In other words, teachers who have positive attitude toward science had high self-efficacy beliefs. Learning environments should be prepared to conduct science activities effectively in accordance with different methods and techniques.

KEY WORDS: preschool teachers; attitude toward science teaching; science self-efficacy belief

\section{INTRODUCTION}

$\mathrm{P}$ reschool education covers the period from the birth of the child to the $1^{\text {st }}$ day of primary education. Its importance is increasing day-by-day. During this period, preschool education institutions aims to shape the personality of children and to prepare them for life by considering their physical, social, emotional, and mental development in the most healthy way of children to spend and aims to prepare them for life (Kandır, 2001). Therefore, preschool education has long-term effects on the development of the child. As Evans and Weikart stated in their studies, the quality of this education is of great importance for the child (Yavuzer, 2004).

Children are interested in exploring the environment and nature from the moment they are born (Aktaş Arnas et al., 2007). In this period, like scientists, they study nature and develop their innate curiosity. They begin to form new schemes in their minds by observing the events around them. They learn about the world with new schemas they have saved in their memories. They may not be able to make systematic observations on their own, but they can test the correctness of thoughts, learn to ask questions and find answers to them, and try and see what happens as a result of what they do (Ünal and Akman, 2006). Children who have feelings of exploring, researching, and questioning the environment constantly asks, touch, and enjoy experimenting by mixing various substances (Erbaş et al., 2002). In this process, the education environment should be arranged in a way to reinforce the curiosity feeling considering all the development areas of the child. Teachers should give importance to this willingness in children.

Preschool teachers have a special importance in a child's life, as they are often the first formal teacher they encounter in life. As a result, it is important for teachers to develop positive attitudes toward science so children who are better able to convert what they learn and experience into behavior later in life. In addition to developing a positive attitude toward science lesson, preschool teachers prepare students for life with the science activities they have done, contribute to their development, by teaching effective thinking styles, and developing problem solving skills (Orkunoğlu, 2016). In addition, science studies in preschool programs consist of activities that help children to know their environment and nature, reveal their thoughts, and ask questions by taking advantage of their curiosities of natural research and investigation (Ünal and Akman, 2006).

1. A part of this study was presented as a summary paper at the $14^{\text {th }}$ National Preschool Education Student Congress, 25-27 April 2019, Maltepe University, İstanbul, TURKEY. 
Although not all children initially show the same interest in science activities in preschool education, the role of the teacher is important here. Preschool teachers need to monitor children's development and be aware of their individual characteristics and structure their teaching accordingly. For this reason, teachers need to have a wide range of teaching skills, recognize the differences in the speed of learning of children, and the ability to organize classroom activities according to these differences. In this way, teachers make a great contribution to children's interest in science. They develop a scientific attitude and behavior by teaching the child the process of finding, collecting, and exploiting information (Lind, 2000; Faulkner-Schneider, 2005). Consequently, misconceptions gained by children from their family and other environments can be corrected and most importantly, science can be enjoyed by children. Teachers should use their curious character and predictive skills to develop children's scientific knowledge and thinking skills. It has been argued that the main purpose of science education in early childhood education is to make better predictions and interpretations because of the child's observations (Aktaş Arnas, 2002). To this end, the teacher should provide children with scientific process skills. It should include studies that will improve children's questioning, observation, testing, and interpretation skills. In science education, the teacher should motivate, encourage, and stimulate the child to initiate a scientific process. At the same time, the teacher should be asking open-ended questions so that all children can express their opinions instead of seeking a single correct answer for the development of children's creativity and problem-solving skills, and provide a safe environment for the child's research and investigation. As such, the competence of preschool teachers in science and the equipment of preschool institutions are of great importance.

Self-efficacy belief was defined by Bandura (1986) as the belief in the capacity of an individual to achieve a certain success. Individuals with high self-efficacy demonstrate more effort to accomplish a job, are more persistent, and patient (Aşkar and Umay, 2001). It has been shown that self-efficacy beliefs affect the practices of teachers in the classroom and the teacher who has strong self-efficacy beliefs is more willing and passionate about teaching (B1kmaz, 2004). However, some studies show that preschool teachers feel themselves scientifically inadequate in science subjects (Ayvac1 et al., 2002; Özbey and Alisinanoğlu, 2008). This situation makes it obligatory for prospective teachers who are educated in preschool programs to receive desired level of education (Dönmez Usta and Ültay, 2017; Ültay and Ültay, 2015).

Preschool teachers' approaches to science subjects, attitudes, and the ability to communicate this knowledge to students through various methods and techniques are directly related to the level of scientific knowledge they possess. Studies show that teachers who do not have enough scientific knowledge spend less time teaching scientific concepts (Appleton, 1992; Cho et al., 2003). Similarly, both Kallery and Psillos (2001) and Saçkes (2014) studies associate the time devoted to science activities with the lack of pedagogical content knowledge of teachers for science education, difficulty in access to resources, and self-efficacy skills of science education. All this shows that the success of teachers' activities for science education or the achievement of effective science education is related to their attitude toward science teaching and their self-efficacy beliefs. From this point of view, the aim of this study was to determine the relationship between pre-school teachers' attitudes toward science teaching and self-efficacy beliefs and to examine them in terms of various variables such as gender and professional experience.

\section{METHODOLOGY}

\section{Research Model}

The method of this study was case study. Case studies aim to investigate the characteristics of a group in depth (Ekiz, 2009). This research was conducted in the years 2018-2019. It included 113 female and eight male preschool teachers who worked in either a state or private school in one city in Turkey. All participants participated voluntarily.

\section{Sample}

Teachers participating in the survey graduated from preschool education or child development programs at various universities and were teaching in Turkey. Forty-one of these teachers had 1-5 years of experience, 37 teachers 6-10 years of experience, 24 teachers $11-15$ years of experience, 11 teachers $16-20$ years of experience, and 8 teachers 21 years or more experience. They were participated in the study as an easy access sampling.

The teachers were coded as T1, T2,.., up to T121 as a requirement in terms of the ethics of the research. The teachers included in the study were informed that some of the data would be shared with the reader and their consent was obtained. It is also stated that they will not be damaged in any way from the research.

\section{Data Collection Tools}

The "Scale of Attitudes toward Science Teaching" (AST) which was adapted to Turkish by Çamlıbel-Çakmak (2006) and the "Science Teaching Self-Efficacy Beliefs Scale" (SEB) which was prepared by Özkan et al. (2002) were offered to the teachers. Both scales consist of five-point Likert type items. The AST consists of 17 items and the SEB 23 items. After the scales were applied, semi-structured interviews were conducted with 36 randomly selected teachers and five openended questions developed by the researchers were asked.

\section{Data Analysis}

Quantitative data were analyzed with IBM SPSS v22 package program. Non-parametric tests were applied in the analysis of quantitative data obtained from the AST since it was not possible to apply parametric tests. Since the $15^{\text {th }}$ and $17^{\text {th }}$ items were negative in the AST, they were reverse coded. Mann-Whitney U-test was used to determine whether there was a significant difference between the groups according to gender and Kruskal-Wallis test was used to determine whether there was a significant difference according to professional experience. In the analysis of quantitative data obtained from 
the SEB, parametric tests were used because the data showed normal distribution and there was no difference between the variances. In the SEB, items $3,6,7,8,10,13,14,16,19$, 20 , and 22 were reverse coded because they were negative. Independent samples $\mathrm{T}$ test was used to determine whether there was a significant difference between the groups according to gender and One-Way ANOVA Test for independent samples was used to determine whether there was a significant difference according to professional experience.

In the analysis of semi-structured interview data, content analysis was used. Accordingly, the interviews recorded with the aid of voice recorder were first transcribed and critical responses were obtained after necessary reductions were made. These critical answers were then placed in appropriate themes and displayed under these themes. Some of the answers given by the teachers are presented to the reader as they are.

\section{Reliability and Validity}

Before the data collection process was started, teachers were informed by the researchers that "applications and data will be used for research purposes only" and that "no data will be shared with the readers of the study except some demographic information." The purpose of this information was to increase the credibility of the study by enabling teachers to respond comfortably and sincerely during the data collection process. In addition, the data collection process was carried out in the environment in which teachers were accustomed, that is, in the institutions where they work.

The reliability coefficient (Cronbach alpha) calculated for the AST used in the study was 0.94 and the calculated reliability coefficient (Cronbach alpha) for the SEB was 0.78. Before the semi-structured interview questions used in the study were applied, an associate professor of Turkish language was approached and his thoughts on intelligibility and appearance validity were asked. Interview questions were prepared in parallel with the items in the scales and an educational sciences specialist checked for the content validity.
Rather than addressing the quantitative and qualitative findings obtained from the data collection tools used in the research from a single point of view, a triangulation technique was utilized (Cohen and Manion, 1989). Thus, quantitative data and qualitative data obtained from teachers supported each other (Çepni, 2007).

To increase the credibility and consistency of the study, the necessary responses were made 3 times in different times and places by the researchers and the critical answers were determined and code pools were created and these codes were tried to be divided into themes/categories. The validity and reliability of these stages were verified by expert opinions. The results obtained from the study should be supported by the data (Miles and Huberman, 1994). This is indicative of the availability confirmation. In this research, direct statements of teachers were given and so it was tried to provide confirmation.

\section{FINDINGS}

The findings of the AST and SEB applied to preschool teachers, and the semi-structured interview conducted with a part of the teachers, which were obtained with the help of IBM SPSS v22 package program, are presented below, respectively.

\section{The Findings of AST}

The statistical data obtained from the AST are shown in Table 1.

According to Table 1, the average of the scale was 4.21; the minimum value was 3.41 , and the maximum value was 4.57 . The normality test was conducted to determine the way in which the data obtained from the AST will be analyzed and the data are presented below.

According to Table 2, the significance value (Sig.) of the normality test is $<0.05$. According to Tabachnick and Fidell (2013), if the significance value (Sig.) is $<0.05$, if the skewness and kurtosis values are between -1.5 and +1.5 , then the data

\section{Table 1: The statistical data of AST}

\begin{tabular}{ccccccccc}
\hline Item Means & Mean & Minimum & Maximum & Range & Maximum/Minimum & Variance & N of items \\
\cline { 2 - 7 } & 4.21 & 3.41 & 4.57 & 1.16 & 1.34 & 0.09 & 17 \\
\hline
\end{tabular}

AST: Scale of attitudes toward science teaching

Table 2: The normality test for AST

\begin{tabular}{|c|c|c|c|c|c|c|c|c|}
\hline \multirow[t]{2}{*}{ AST total } & \multirow[t]{2}{*}{ Skewness } & \multirow[t]{2}{*}{ Kurtosis } & \multicolumn{3}{|c|}{ Kolmogorov-Smirnov ${ }^{\mathrm{a}}$} & \multicolumn{3}{|c|}{ Shapiro-Wilk } \\
\hline & & & Statistic & df & Sig. & Statistic & df & Sig. \\
\hline & -2.02 & 7.01 & 0.13 & 121 & 0.00 & 0.83 & 121 & 0.00 \\
\hline
\end{tabular}

a. Lillie fors significance correction. AST: Scale of attitudes toward science teaching

Table 3: Mann-Whitney U-test data according to gender variable of AST

\begin{tabular}{lccccccc}
\hline Gender & $\mathbf{n}$ & Mean rank & Sum of ranks & Mann-Whitney U & Wilcoxon W & Z & Asymp. sig. (two-tailed) \\
\hline Female & 113 & 60.92 & 6884.50 & 443.50 & 6884.50 & -0.09 & \\
Male & 8 & 62.06 & 496.50 & & & \\
Total & 121 & & & & & \\
\hline
\end{tabular}

AST: Scale of attitudes toward science teaching 


\begin{tabular}{lccccc}
\hline \multicolumn{4}{l}{ Table 4: Kruskal-Wallis test data according to AST's } & professional experience variable & \\
\hline Professional experience & $\mathbf{n}$ & Mean rank & Chi-square & df & Asymp. sig. \\
\hline $1-5$ years & 41 & 59.78 & 0.32 & & \\
$6-10$ years & 37 & 59.64 & & \\
$11-15$ years & 24 & 63.10 & & \\
$16-20$ years & 11 & 64.59 & & \\
21 years and over & 8 & 62.31 & & \\
Total & 121 & & & & \\
\hline
\end{tabular}

AST: Scale of attitudes toward science teaching

Table 5: The statistical data of SEB

\begin{tabular}{cccccccc}
\hline Item Means & Mean & Minimum & Maximum & Range & Maximum/Minimum & Variance & N of items \\
\cline { 2 - 7 } & 3.69 & 1.88 & 4.42 & 2.55 & 2.36 & 0.39 & 23 \\
\hline
\end{tabular}

SEB: Science teaching self-efficacy beliefs scale

are considered to be normal. However, as can be seen from the table, these values are not between -1.5 and +1.5 and the data do not show normal distribution. Therefore, non-parametric tests were used in the analyzes since the requirement for applying parametric tests could not be provided. MannWhitney U-test was used to determine whether there is a significant difference between the groups according to gender variable and test data are presented in Table 3.

According to Table 3 , sig. value (two-tailed) is $>0.05$, there was no significant difference between the gender groups according to AST data. In addition, Kruskal-Wallis test was applied to determine whether there was a significant difference between the groups according to the professional experience variable and test data are presented in Table 4.

According to Table 4, because the sig. value was $>0.05$, there was no significant difference between professional experience groups according to AST data.

\section{The Findings of the SEB}

The statistical data obtained from SEB are shown in Table 5.

According to the table, the average of the scale was 3.69; the minimum value was 1.88 , and the maximum value was 4.42 . Normality and homogeneity of variance tests were conducted to determine the way, in which the data obtained from the SEB were analyzed and the data are presented in Table 6.

According to Table 6, Kolmogorov-Smirnov test significance value (Sig.) 0.05 was considered to be a normal distribution of the data. To benefit from parametric tests, the variances should be homogeneous as well as the normal distribution of the data. Therefore, Table 7 presents the data for the test of homogeneity of variances.

According to Table 7, the significance value (Sig.) was $>0.05$. Therefore, it was assumed that the variances were homogeneous. The fact that the number of samples was above 30 , the normal distribution of the data and the absence of differences between the variances indicate that the data can be analyzed by parametric tests. To determine whether there
Table 6: The normality test for SEB

\begin{tabular}{cccccccc}
\hline SEB total & \multicolumn{3}{c}{ Kolmogorov-Smirnov $^{\mathrm{a}}$} & & \multicolumn{3}{c}{ Shapiro-Wilk } \\
\cline { 2 - 4 } \cline { 5 - 6 } & Statistic & df & Sig. & & Statistic & df & Sig. \\
\hline 0.06 & 121 & $0.20^{*}$ & & 0.98 & 121 & 0.04
\end{tabular}

*. This is a lower bound of the true significance. a. Lilliefors significance correction. SEB: Science teaching self-efficacy beliefs scale

Table 7: Homogeneity of variance test data of SEB

\begin{tabular}{lccc}
\hline Levene statistic & df1 & df2 & Sig. \\
\hline 0.28 & 4 & 116 & 0.89 \\
\hline
\end{tabular}

SEB: Science teaching self-efficacy beliefs scale

Table 8: The statistical data of SEB according to the gender

\begin{tabular}{lcccc}
\hline Gender & N & Mean & Std. deviation & Std. error mean \\
\hline Female & 113 & 84.55 & 7.91 & 0.74 \\
Male & 8 & 80.75 & 10.89 & 3.85 \\
\hline
\end{tabular}

SEB: Science teaching self-efficacy beliefs scale

was a significant difference between the groups according to gender, independent samples $t$-test was applied, and test data are presented in Tables 8 and 9 .

According to Table 9, since the sig. value (two-tailed) value was $>0.05$, there was no significant difference between the gender groups according to the SEB data. In addition, one-way ANOVA test was used for independent samples to determine whether there was a significant difference between the groups according to professional experience variable and test data were presented in Tables 10 and 11.

According to Table 11, there was no significant difference between the professional experience groups according to the SEB data because the value was $>0.05$. Pearson moments correlation coefficient was calculated to determine whether there was a relationship between teachers' attitudes toward science and science self-efficacy. Correlation data are presented in Table 12. 


\begin{tabular}{lccccccc}
\hline \multicolumn{2}{l}{ Table 9: Independent samples } & $\boldsymbol{t}$-test & of SEB for & \\
\hline Variances & $\mathbf{F}$ & $\mathbf{S i g}$ & $\mathbf{t}$ & $\mathbf{d f}$ & Sig. (2-tailed) & Mean difference & Std. error difference \\
\hline Equal variances assumed & 0.63 & 0.43 & 1.28 & 119 & 0.20 & 3.80 & 2.97 \\
Equal variances not assumed & & & 0.97 & 7.53 & 0.36 & 3.80 & 3.92 \\
\hline
\end{tabular}

SEB: Science teaching self-efficacy beliefs scale

\begin{tabular}{|c|c|c|c|c|c|c|}
\hline Professional experience & $\mathbf{n}$ & Mean & Std. deviation & Std. error & Minimum & Maximum \\
\hline $1-5$ years & 41 & 84.83 & 7.94 & 1.24 & 62.00 & 98.00 \\
\hline $6-10$ years & 37 & 83.51 & 8.37 & 1.38 & 61.00 & 100.00 \\
\hline $11-15$ years & 24 & 83.17 & 8.11 & 1.66 & 60.00 & 101.00 \\
\hline $16-20$ years & 11 & 87.73 & 8.32 & 2.51 & 74.00 & 98.00 \\
\hline 21 years and over & 8 & 83.88 & 8.46 & 2.99 & 76.00 & 99.00 \\
\hline Total & 121 & 84.30 & 8.14 & 0.74 & 60.00 & 101.00 \\
\hline
\end{tabular}

SEB: Science teaching self-efficacy beliefs scale

\begin{tabular}{lccccc}
\hline $\begin{array}{l}\text { Table 11: One-way ANOVA of SEB for professional } \\
\text { experience }\end{array}$ & \\
\hline Groups & Sum of squares & df & Mean square & F & Sig. \\
\hline Between groups & 195.90 & 4 & 48.96 & 0.73 & 0.57 \\
Within groups & 7749.44 & 116 & 66.81 & & \\
Total & 7945.29 & 120 & & & \\
\hline
\end{tabular}

SEB: Science teaching self-efficacy beliefs scale

$\begin{aligned} & \text { Table 12: Pearson moments correlation test data between } \\
& \text { AST and SEB }\end{aligned}$
\begin{tabular}{llcc}
\hline Items & Correlation test & AST total & SEB total \\
\hline AST total & Pearson correlation & 1 & $0.33^{* *}$ \\
& Sig. (two-tailed) & & 0.00 \\
& $n$ & 121 & 121 \\
SEB total & Pearson correlation & $0.33^{* *}$ & 1 \\
& Sig. (two-tailed) & 0.00 & \\
& $n$ & 121 & 121 \\
\hline
\end{tabular}

*** Correlation is significant at the 0.01 level (2-tailed). SEB: Science teaching self-efficacy beliefs scale, AST: Scale of attitudes toward science teaching

According to Table 12, there was a positive (Pearson Correlation $=0.33)$ and significant $(\mathrm{P}<0.01)$ relationship between science attitudes and science self-efficacy of teachers.

\section{The Findings of Semi-Structured Interview}

The findings of the semi-structured interview with preschool teachers are presented in Table 13.

According to the answers given to the first question of the interview, the theme of "very happy if successful" was the most repeated theme. For example, the teacher with the code T84 stated:

I like to try and want children see it. If the children finish the activities successfully and happily, I am happy too. I'm trying to determine the effects on children in my activities and I'm trying to motivate children for the next activity.
Table 13: Findings of the first question of the interview

Question 1: How do you feel about doing science activities in the classroom? Please explain in detail.

\begin{tabular}{lcc}
\hline Theme & Teacher (T) & $f$ \\
\hline Very happy if successful & $7,27,40,43,58,78,79,81,84,85$, & 12 \\
& 96,108 & \\
Comfortable & $11,17,22,40,41,55,56,69,104$, & 11 \\
Pleasant, fun & 113,115 & \\
Excited & $6,32,68,74,78,81,85,90$ & 8 \\
Productive as a scientist & $71,93,111,113$ & 4 \\
Stressed, anxious & $9,49,79$ & 3 \\
Motivated, eager & $11,107,115$ & 3 \\
Ready & 21,45 & 2 \\
Self-confident & 41 & 1 \\
Like a magician & 111 & 1 \\
\hline
\end{tabular}

The T7 coded teacher likewise noted:

I feel very good and happy when I have had a lot of fun and success in doing science activities with my students. Because I enjoy teaching them new knowledge. If the activity is not the way I want it to be, I would like to learn myself and aim to be more successful.

The teacher with the code T11 answered the same question:

I feel more comfortable, give detailed information, and make observations about the subjects that I have mastered in science activities. But sometimes I can get stuck on something I don't have much control. In order not to experience tension, I am trying to obtain detailed information beforehand

Her answer was placed under both "relaxed" and "tense, anxious, stressful" themes.

According to the answers to the second question of the interview, the theme of "provision of materials in advance" was the most repetitive theme. For example, the teacher with T104 code said that "first of all, I do research on the internet for the science 


\begin{tabular}{|c|c|c|}
\hline \multicolumn{3}{|c|}{$\begin{array}{l}\text { Question 4: In your opinion, what role does teacher have in student } \\
\text { learning for science activities? Please explain the reasons. }\end{array}$} \\
\hline Theme & Teacher (T) & $f$ \\
\hline $\begin{array}{l}\text { Motivator/ Intriguing/ } \\
\text { Informative }\end{array}$ & $\begin{array}{c}6,7,8,17,32,49,55,56,58,68 \\
69,78,79,84,85,90,93,96,104 \\
108,111\end{array}$ & 21 \\
\hline Guide & $\begin{array}{c}6,8,11,17,22,27,43,56,58,79 \\
81,104,107,108,115\end{array}$ & 15 \\
\hline $\begin{array}{l}\text { Presenting the information/ } \\
\text { Explanatory/Teachers }\end{array}$ & $7,27,41,45,71,84,85$ & 7 \\
\hline Role model & $9,74,78$ & 3 \\
\hline Unsuitable answer & $21,40,113$ & 3 \\
\hline
\end{tabular}

Table 15: Findings of the third question of the interview

Question 3: What methods do you prefer when you have a science activity in the classroom? Please explain the reasons.

\begin{tabular}{lcc}
\hline Theme & Teacher (T) & $f$ \\
\hline Field trips and observation & $7,11,21,22,27,32,40,43,45$, & 17 \\
& $58,71,74,78,79,85,90,107$ & \\
Experiment & $22,27,32,40,41,43,68,69$, & 14 \\
\multicolumn{3}{c}{$71,74,79,104,107,108$} \\
Demonstration and make them & $7,8,11,17,56,58,79,81,84$, & 13 \\
repeat & $93,96,111,115$ \\
Learning by doing & $6,9,55,71,78,79,90,113$ & 8 \\
Question and answer and & $17,27,55,56,58,93,96$ & 7 \\
brainstorming & $11,55,56,58,69$ & 5 \\
Lecturing & $27,55,56$ & 3 \\
Trial and error & $69,74,108$ & 3 \\
Dramatization & 40,104 & 2 \\
Play and music & 40,43 & 2 \\
Project & 40 & 1 \\
Analogy & 81 & 1 \\
Explaining the activity by the & & \\
student & 49 & 1 \\
Induction and deduction & &
\end{tabular}

activity I will have. I choose the most appropriate activity for children and make the materials ready for them," and this answer was placed under "provision of materials in advance," "seating/setting up the environment," "prior research," and "determination of appropriate method and activity/experiment." The same question was answered by the teacher with the code T21 with: According to the activity I will prepare the class in the best way to attract children's attention. In this way, I will reduce the problems that will arise in the event. I planned the event's plan in advance and gave only attention to practice on that day.

This answer was placed under the themes of "pre-experiment" and "motivator/drawing attention."

According to the answers given to the third question of the interview, "field trips, and observation" theme was the most repeated theme. The answer of the teacher coded T7 was placed under the themes of "field trips and observation" and "demonstration and make them repeat" with this statement:
Table 16: Findings of the second question of the interview

Question 2: What kind of preparation process do you have before you have a science activity in the classroom? Please explain in detail.

\begin{tabular}{|c|c|c|}
\hline Theme & Teacher $(\mathrm{T})$ & $f$ \\
\hline $\begin{array}{l}\text { Provision of materials in } \\
\text { advance }\end{array}$ & $\begin{array}{c}7,8,9,27,32,40,45,49,55,68,69 \\
71,81,84,85,90,93,96,104,108 \\
111,113,115\end{array}$ & 23 \\
\hline Pre-experiment & $\begin{array}{c}9,11,17,21,22,32,40,41,55,74 \\
78,79,96,107,111\end{array}$ & 15 \\
\hline $\begin{array}{l}\text { Seating/Setting up the } \\
\text { environment }\end{array}$ & $\begin{array}{c}7,8,22,27,32,40,68,71,81,84 \\
85,104,115\end{array}$ & 13 \\
\hline Prior research & $6,11,17,32,40,45,85,90,93,104$ & 10 \\
\hline $\begin{array}{l}\text { Motivator/drawing } \\
\text { attention }\end{array}$ & $6,7,17,21,49,56,58,68,85$ & 9 \\
\hline $\begin{array}{l}\text { Determination of } \\
\text { appropriate method and } \\
\text { activity/experiment }\end{array}$ & $22,71,74,78,90,93,96,104$ & 8 \\
\hline $\begin{array}{l}\text { Preparing a plan/Making } \\
\text { planning }\end{array}$ & $56,78,84,85,96$ & 5 \\
\hline $\begin{array}{l}\text { Giving preliminary } \\
\text { information }\end{array}$ & $7,8,11,45$ & 4 \\
\hline $\begin{array}{l}\text { Giving information } \\
\text { about the activity/ } \\
\text { experiment }\end{array}$ & 84,96 & 2 \\
\hline $\begin{array}{l}\text { Taking short notes in } \\
\text { advance }\end{array}$ & 40,41 & 2 \\
\hline $\begin{array}{l}\text { Ask the student to do } \\
\text { research in advance }\end{array}$ & 43 & 1 \\
\hline
\end{tabular}

\section{Table 17: Findings of the fifth question of the interview \\ Question 5: In your opinion, what can be done to teach science activities more effectively? Please explain the reasons.}

\begin{tabular}{|c|c|c|}
\hline Theme & Teacher $(\mathrm{T})$ & $f$ \\
\hline $\begin{array}{l}\text { Increasing the active } \\
\text { participation of students }\end{array}$ & $\begin{array}{c}7,8,17,32,49,55,58,69,71,79 \\
84,104,107,108,111,113,115\end{array}$ & 17 \\
\hline $\begin{array}{l}\text { Increasing the number of the } \\
\text { materials/Renovation and } \\
\text { regulation of the physical } \\
\text { environment }\end{array}$ & $\begin{array}{c}8,11,22,43,45,71,79,93,96 \\
113\end{array}$ & 10 \\
\hline $\begin{array}{l}\text { Increasing the number of the } \\
\text { trips/observations }\end{array}$ & $9,11,17,45,74,78,79,85,90$ & 9 \\
\hline $\begin{array}{l}\text { Use of different methods and } \\
\text { techniques }\end{array}$ & $69,81,104,107,108$ & 5 \\
\hline Relating with real life & $21,27,78,85,108$ & 5 \\
\hline $\begin{array}{l}\text { Teacher's professional } \\
\text { development }\end{array}$ & $11,41,84,115$ & 4 \\
\hline Avoiding lecturing & $8,68,115$ & 3 \\
\hline Using the real objects & $6,7,74$ & 3 \\
\hline $\begin{array}{l}\text { Increasing the number of the } \\
\text { experiments }\end{array}$ & 11,93 & 2 \\
\hline Giving seminars to teachers & 56,58 & 2 \\
\hline $\begin{array}{l}\text { Ensuring family } \\
\text { participation }\end{array}$ & 56 & 1 \\
\hline $\begin{array}{l}\text { Determination of students' } \\
\text { prior knowledge }\end{array}$ & 40 & 1 \\
\hline
\end{tabular}

I prefer the method of demonstration and make them repeat because an effective learning environment is created when by 
visual and auditory elements are used. I also prefer to make field trips and observation because the places that the students are seen are stayed longer in their minds.

The teacher with the code T69 answered the same question with "I use methods such as lecturing, dramatization, and experiment. Before the experiment or other science methods, I give detailed explanations to children and apply them" and her answer was placed under the themes of "experiment," "lecturing," and "dramatization."

According to the answers given to the fourth question of the interview, the theme of "motivator/intriguing/informative" was the most repetitive theme. For example, the teacher coded as T6 noted the "Teacher has a role as a guide. It should prioritize children's learning by living. He must lead the children's curiosity and lead their experiments. It should help them to reach information." T6's comments were placed under the themes of "guide" and "motivator/intriguing/informative." The T9 coded teacher said, "The student already takes the teacher as a role model all the time. The fact that the teacher is knowledgeable and visible, being organized, and willing while doing the activities will also affect the students." As such, T9's ideas were placed under the "role model" theme.

According to the answers given to the fifth question of the interview, the theme of "increasing the active participation of students" was the most repeated theme. For example, the teacher coded T17 said "The activities that will make the child active should be given more time and the travel arrangements should be more involved in the school activities as the trips can be more effective for on-site learning" and her words were placed under "increasing the active participation of the students" and "increasing the number of the trips/ observations,." The T21 coded teacher reported:

It is very important for children to be able to relate to life and give concrete examples to make science activities more effective. This is because the child can relate the science activity to his own life. I think that this makes the activity more permanent and effective for the child.

These comments were placed under "relating with real life."

\section{DISCUSSION, CONCLUSION, AND IMPLICATIONS}

In this study, the relationship between preschool teachers' attitudes toward science teaching and self-efficacy beliefs was investigated and examined in terms of gender and professional experience. In the light of the findings obtained from the study, it was seen that preschool teachers' attitudes toward science teaching and science self-efficacy beliefs did not differ according to gender and professional experience.

According to Kaptan's (1998) chart, when the science attitude averages of preschool teachers are taken into consideration, it can be said that the average is quite high and therefore their attitudes toward science are positively high. This shows that teachers have positive feelings toward the science course and therefore give importance to this course (Ültay et al., 2019; Ültay et al., 2020). Since the positive attitude and perspective of the teacher toward science will be a role model for the student, it will create great differences in the perspective of the student (Orkunoğlu, 2016). As a matter of fact, in the fourth question of the interview (Table 14), when asked the role of the teacher in the learning of the students, the majority of the teachers gave answers in the theme of "motivating, intriguing, and informative." In other words, teachers were the primary people who were responsible for the student's learning. Teachers who did not have a positive attitude toward the course cannot be expected to discover and respond to the interests and needs of a student who is interested in research as a natural scientist.

When the mean scores of preschool teachers' science selfefficacy beliefs were examined, it is seen that teachers often felt themselves sufficient. In this case, it could be said that teachers would allocate sufficient time for science activities in the classroom and contribute positively to the students' scientific process skills while making the activities (Dönmez Usta and Ültay, 2017). In addition, in the first question of the interview (Table 13), the majority of the teachers used positive words to the question of how do you feel when you were doing science activities. Only two teachers stated that sometimes they felt relaxed and sometimes tense, anxious, or stressed. They said it was all about the science topic itself. They stated that they felt comfortable in an activity that they knew the content of the subject well, but they felt tense about a subject they did not know well. In this case, a teacher who feels tense cannot be expected to encourage students to ask questions and to conduct research. According to Clancey (1987), teachers with low level of content knowledge provide classroom instruction at the knowledge level (according to Blomm's taxonomy), apply teacher-centered methodology, constantly ask students the same kind of questions, and try to conduct the lesson within the framework of their own narrow content knowledge. Therefore, students ask less questions and focus more on the same questions. On the other hand, teachers with a high level of content knowledge adopt conceptual education. They are more open to interpretation, ask different questions, apply a student-centered method, create a classroom environment where teacher dominance is low, and students' answers are open to evaluation.

According to Britner and Pajares (2006), self-efficacy has been found to be a strong predictor of academic achievement, course selection, and career decisions across domains and age levels. Self-efficacy beliefs affect an individual's academic performance by affecting many behavioral and psychological processes (Bandura, 1986). From this point of view, people who think that they can achieve science can find enough motivation to complete their science activities no matter how hard they are, or how much effort they make. However, individuals with low self-efficacy beliefs will avoid doing science-related activities or tasks, and even if they do, they will not be successful in many tasks they can accomplish. 
Because their motivation is low, their anxiety levels are also high (Britner and Pajares, 2006; Shell et al., 1995).

For example, Cannon and Scharmann (1996) explained Bandura's speculations in their research: If one has had a negative experience with a science course, one probably will expect the next science course to be much the same based on experience. The person also will likely behave in and cope with the course as they have in the past. (p. 420)

From this point of view, it can be said that self-efficacy is an important attribute in effective science teaching (Czerniak and Waldon, 1991; Enochs and Riggs, 1990). From this point of view, it can be said that the teacher's belief in science selfefficacy must be high for effective science teaching. As a matter of fact, when the interview data were examined, those who defined themselves as comfortable, pleasant, and fun while having science activities (Table 13) also suggested more than one method for effective science teaching, for example, T11 coded teacher in Table 15.

There was a positive relationship between teachers' scores from the AST and SEB, that is, science attitudes and science self-efficacy beliefs were related. In other words, teachers who had a positive attitude toward science had high self-efficacy beliefs. Similarly, in national and international studies, selfefficacy beliefs of teachers with high attitudes toward their professions were found to be high (Ashton, 1984; Denizoğlu, 2008; Gibson and Dembo, 1984, Ramey-Gassert and Shroyer, 1992). Considering the characteristics of teachers with positive attitude toward science and the characteristics of teachers with high self-efficacy beliefs, they have similar characteristics. Teachers with positive attitudes toward science provide more effective learning by creating a more productive learning environment like teachers with a high belief in science selfefficacy and encouraging students in the classroom to ask questions. When the answers given to the second question of the interview were examined (Table 16), it was seen that teachers who had positive attitudes toward science provided more than one pre-preparation methods to make effective teaching before having science activities (e.g., T6, 7, 8, and 11 coded teachers). Similarly, when Table 15 is examined, it is seen that these teachers continue their activities with more than one method during science activities. In addition, as it was seen in the fourth question of the interview (Table 14) that the teacher has "motivating/intriguing/informative" and "guiding" characteristics during science activities. To demonstrate these characteristics, a teacher must have developed a positive attitude toward science and a high self-efficacy belief. It was seen that a teacher with a positive attitude toward science was able to transfer this attitude to his students and then they were willing to work on science-related subjects (Mattern and Schau, 2002).

Teachers are the ones who use their skills effectively in facilitating, endearing, and guiding learning to provide an efficient education and training environment. For teachers to use knowledge, skills, and abilities effectively in the educational environment, their affective characteristics about their professions are important. For this reason, self-efficacy and attitudes are the main variables that affect teachers' professional achievement (Denizoğlu, 2008). In this context, it is necessary to provide training in institutions that provide the foundation of teachers' science attitudes and self-efficacy perceptions. According to Doyle (1997), the high self-efficacy and attitudes of teachers are closely related to the education given in the faculties of education. Because preservice teachers need to be organized in a way to respond to their interests and need before they can develop positive attitudes toward their professions and high self-efficacy beliefs. In the fifth question of the interview (Table 17), to make science activities more effective, the teachers stated that the activities that ensure the active participation of the students should be preferred the most. However, other suggestions are directly related to the education received by the teachers in the faculties of education. Learning environments prepared in accordance with different methods and techniques and being able to conduct science activities effectively are also directly related to the curricula of teacher training institutions. From this point of view, it may be suggested that faculties of education should rearrange their curricula in a way that improves teachers' attitudes and self-efficacy beliefs.

\section{REFERENCES}

Aktaş Arnas, Y. (2002). Objectives of science education in preschool period. Journal of Child Development and Education, 6(7), 1-6.

Aktaş Arnas, Y., Aslan, D., \& Bilaloğlu, G.R. (2007). Science Education in Preschool Period. United States: Kök Publishing.

Appleton, K. (1992). Discipline knowledge and confidence to teach science: Self-perceptions of primary teacher education students. Research in Science Education, 22(1), 11-19.

Ashton, P.T. (1984). Teacher efficacy: A motivational paradigm for effective teacher education. Journal of Teacher Education, 35, 38-32.

Aşkar, P., \& Umay, A. (2001). Perceived computer self-efficacy of the students in the elementary mathematics teaching programme. Hacettepe University Journal of Education, 21, 1-8.

Ayvacı, H.Ş., Devecioğlu, Y., \& Yiğit, N. (2002). Determining the Competence of Preschool Teachers in Science and Nature Activities. Ankara, Turkey: Paper Presented at $5^{\text {th }}$ National Science and Mathematics Education Congress.

Bandura, A. (1986). The explanatory and predictive scope of self-efficacy theory. Journal of Social and Clinical Psychology, 4(3), 359-373.

B1kmaz, F.H. (2004). Validity and reliability study of self-efficacy belief scale in science teaching of primary teachers. Journal of National Education, 31(161), 172-180. Available from: http://www.dhgm.meb. gov.tr/yayimlar/dergiler/milli_egitim_dergisi/161/bikmaz.htm. [Last accessed on 2020 Feb 01]

Britner, S.L., \& Pajares, F. (2006). Sources of science self-efficacy beliefs of middle school students. Journal of Research in Science Teaching, 43(5), 485-499.

Çamlıbel-Çakmak, Ö. (2006). Investigation of the Relationship Between Preschool Pre-service Teachers Attitudes Towards Science and a Science Teaching and Their Understaning Levels of Some Science Concepts. Bolu, Turkey: Unpublished Master Dissertation, Abant İzzet Baysal University.

Cannon, J.R., \& Scharmann, L.C. (1996). Influence of a cooperative early field experience on preservice elementary teachers' science self-efficacy. Science Education, 80(4), 419-436.

Çepni, S. (2007). Introduction to Research and Project Work. United States: Celepler Printing.

Cho, H., Kim, J., \& Choi, D.H. (2003). Early childhood teachers' attitudes 
toward science teaching: A scale validation study. Educational Research Quarterly, 27(2), 33-42. Available from: https://www.search. proquest.com/openview/51d8e64cc03fbdd276f19f872f156766/1?pqorigsite $=$ gscholar\&cbl $=48020$. [Last accessed on 2020 Jan 12].

Clancey, W.J. (1987). Knowledge-based Tutoring: The Guidon Program. Tamil Nadu: MIT Press.

Cohen, L., \& Manion, L. (1989). Research Methods in Education. $4^{\text {th }}$ ed. United States: Routledge.

Czerniak, C., \& Waldon, M. (1991). A Study of Science Teaching Efficacy Using Qualitative and Quantitative Research Methods. Lake Geneva, WI: Paper Presented at the Annual Meeting of the National Association of Research in Science Teaching.

Denizoğlu, P. (2008). The Assessment of the Relation Between Self-efficacy Belief Levels, Learning Styles of Science Teacher Candidates Towards Science Teaching, and Their Attitudes Towards Science Teaching. Adana, Turkey: Unpublished Master Dissertation, Cukurova University.

Dönmez Usta, N., \& Ültay, N. (2017). Determination of preschool teachers' abilities on practicing science and nature activities. Eurasian Journal of Researches in Social and Economics, 4(9), 19-30.

Doyle, M. (1997). Beyond life history as a student: Preservice teachers' beliefs about teaching and learning. College Student Learning, 31(4), 519-532.

Ekiz, D. (2009). Scientific Research Methods. $9^{\text {th }}$ ed. New Delhi: An1 Publishing.

Enochs, L.G., \& Riggs, I.M. (1990). Further development of an elementary science teaching efficacy belief instrument: A preservice scale. School Science and Mathematics, 90(8), 694-706.

Erbaş, S., Ergül, R., Şimşekli, Y., \& Özdilek, Z. (2002). Science Teaching in Preschool Period. Kolkata: Ekin Publishing.

Faulkner-Schneider, L.A (2005). Child Care Teachers' Attitudes, Beliefs, and Knowledge Regarding Science and the Impact on Early Childhood Learning Opportunities. Oklahoma: Unpublished Master Dissertation, University of Oklahoma.

Gibson, S., \& Dembo, M.H. (1984). Teacher efficacy: A construct validation. Journal of Educational Psychology, 76, 569-582.

Kallery, M., \& Psillos D. (2001). Pre-school teachers' content knowledge in science: Their understanding of elementary science concepts and of issues raised by children's questions. International Journal of Early Years Education, 9(3), 165-179.

Kandir, A. (2001). The role and importance of preschool education institutions in child development. Journal of National Education, 151, 102-104. Available from: http://www.dhgm.meb.gov.tr/yayimlar/ dergiler/milli_egitim_dergisi/151/kandir.htm. [Last accessed on 2020 Feb 14].

Kaptan, S. (1998). Scientific Research Techniques and Statistical Methods. Washington, DC: Tekışık Printing.

Lind, K.K. (2000). Exploring Science in Early Childhood Education. $3^{\text {rd }}$ ed.
Delmar Albany: SAGE Publications Ltd.

Mattern, N., \& Schau, C. (2002). Gender differences in science attitudeachievement relationships over time among white middle-school students. Journal of Research in Science Teaching, 39(4), 324-340.

Miles, M.B., \& Huberman, A.M. (1994). Qualitative Data Analysis. $2^{\text {nd }}$ ed. United States: SAGE Publications, Inc.

Orkunoğlu, Y.M. (2016). Study of the Relationship Between Preschool Teachers' Science Teaching and Self-efficacy Levels (Ataşehir, District of İstanbul Sample). İstanbul: Unpublished Master Dissertation, Yeditepe University.

Özbey, S., \& Alisinanoğlu, F. (2008). Identifying the general ideas attitudes and expectations pertaining to science activities of the teachers employed in preschool education. Journal of Turkish Science Education, 5(2), 82-94.

Özkan, Ö., Tekkaya, C., \& Çakıroğlu, J. (2002). Science Teachers' Understanding of Science Concepts, Attitude Towards Science Teaching and Self-efficacy Beliefs. Ankara: Paper Presented at $5^{\text {th }}$ National Science and Mathematics Education Congress.

Ramey-Gassert, L., \& Shroyer, M.G. (1992). Enhancing science teaching self-efficacy in preservice elementary teachers. Journal of Elementary Science Education, 4, 26-34.

Saçkes, M. (2014). How often do early childhood teachers teach science concepts? Determinants of the frequency of science teaching in kindergarten. European Early Childhood Education Research Journal, 22(2), 169-184.

Shell, D.F., Colvin, C., \& Bruning, R.H. (1995). Self-efficacy, attribution, and outcome expectancy mechanisms in reading and writing achievement: Grade-level and achievement-level differences. Journal of Educational Psychology, 87(3), 386-398.

Tabachnick, B.G., \& Fidell, L.S. (2013). Using Multivariate Statistics. United Kingdom: Pearson.

Ültay, N., \& Ültay, E. (2015). A cross-sectional determination of the conceptual knowledge of preschool prospective teachers about some scientific concepts. The Journal of International Social Research, 8(41), 1046-1051.

Ültay, N., Dönmez Usta, N., \& Ültay, E. (2020). Investigation of the effects of self-efficacy for science education on learning approaches and perceptions of learning-teaching environment. IBAD Journal of Social Sciences, 5(8), 1-13

Ültay, N., Ültay, E., \& Çilingir, S.K. (2019). Investigation of environmental knowledge levels and attitudes of preservice pre-school teachers in terms of various variables. Mediterranean Journal of Educational Research, 13(28), 173-185.

Ünal, M., \& Akman, B. (2006). Early childhood teachers' attidutes towards science teaching. Hacettepe University Journal of Education, 30, 251-257.

Yavuzer, H. (2004). Knowing and Understanding the Child. United States: Remzi Publishing. 